\title{
SAÚDE DA FONOAUDIOLOGIA NO BRASIL
}

Mesmo antes do reconhecimento formal da profissão de Fonoaudiólogo no Brasil em 1981, a área já se mostrava inquieta, ebuliente, e algumas vezes conteciosa, com pioneiros de várias linhas e escolas debatendo a abrangência de nossa esfera de atuação, direitos e responsabilidades, estruturas curriculares, inserções no mercado de trabalho, nos serviços de saúde e na educação, enfim, nosso perfil profissional.

Debates similares também ocorreram e ainda ocorrem em outros países, e a área tem diferentes características, competências, e estruturas em diferentes partes do mundo. Essa diversidade de perfil é derivada das diferentes realidades socio-econômicas e culturais entre países ou regiões, e na minha opinião, ela é positiva pois nos desafia a avaliar e buscar formas de enriquecer a profissão.

Com a evolução na educação e no cuidado do ser humano torna-se cada vez mais claro o valor de equipes multidisciplinares e multiprofissionais. Esta conjunção de grupos mantem vivo o debate sobre a esfera de atuação de cada profissão, em tentativas de conter a exata atribuição de cada um. Parecem ser inevitáveis as negociações territoriais entre diferentes profissões e muito do tempo e recursos de entidades de classe como conselhos, sociedades, academias são dispendidos nesse exercício . Essa forma de atuação profissional, junto as nossas entidades, é importantíssima para a saúde de nossa profissão.

Outras formas de atuação fundamentais involvem o exercício da profissão em si, e a participação em pesquisa. Por um lado, a presença crescente de fonoaudiólogos no mercado de trabalho e o crescimento e amadurecimento da produção científica nacional ilustram resultados e conquistas passadas da Fonoaudiologia. Por outro lado, essa produção comprova que a área é dinamica, que muitos de nossos profissionais são pioneiros, que buscam e aplicam novos conhecimentos e tecnologias, e assim, continuamente esculpem e ampliam nossa competência . Nossas publicações em periódicos como este, submetidas ao escrutínio de nossos pares, atingem o mundo, abrem portas, sugerem novas perspectivas, enriquecem o dialógo e fortalecessem a área.

O impacto desse conjunto de atuações vão muito além do simples fortalecimento da profissão. Pela natureza de nossa área, o fortalecimento de nossa profissão traz com ele melhorias nítidas nos serviços e atendimentos à população, avanços em educação e saúde.

Quando eu revisava este editorial ganhei um presente: a notícia de que no dia 2 de agosto de 2010 o presidente Luiz Inácio Lula da Silva sancionou a Lei № 12.303 que torna obrigatória a realização exame de Emissões Otoacústicas Evocadas em neonatos. Trata-se de um exemplo perfeito do ponto que quero aqui dividir com vocês. Foi a atuação de nossos profissionais nas diferentes esferas: nas nossas entidades de classe, na excelência no exercício de nossa profissão, com uma base sólida que construímos através de pesquisa, que tornou este sonho uma realidade. Por isso repito aqui o que o Conselho Federal de Fonoaudiologia publicou na sua site: "A conquista é um marco para a saúde auditiva brasileira. Parabéns aos fonoaudiólogos e a todos os setores da sociedade que intervieram para alcançarmos este resultado!" (http://www.fonoaudiologia.org.br/servlet/ConsultaNoticia?acao= V\&notld=179).

Quando tive a honra de ser convidada a escrever este editorial, conhecendo o CEFAC e a Revista CEFAC, esperava uma certa diversidade de temas que ofereceriam ao leitor um panorama atual da profissão. Mesmo assim, me supreendi com a abrangência dos temas abordados neste fascículo: voz cantada, fonação reversa, estética facial, eletromiografia, Síndrome de Kabuki, voz pós-radioterapia, AIDS, desempenho ortográfico e textual - Uau! De crianças a adolescentes, de adultos ao envelhecimento, todos foram comtemplados. Fonoaudiologia quase que onipresente, incontível, batendo em muitas portas, cavando espaços aonde quer que ela vá...

Rev. CEFAC. 2010 Jul-Ago; 12(4):527-714 
De tempos em tempos, se examina a saúde da ciência. Lendo a produção científica brasileira, lendo este fascicúlo eu digo que a saúde da Fonoaudiologia Brasileira vai muito bem. Os avanços - teóricos e práticos - dos profissionais que se dedicam à integridade da comunicação incluídos aqui mostram ao leitor de forma inequívoca que a Fonoaudiologia no Brasil é área consolidada, produtiva e vibrante. Todos nós temos motivos para nos orgulhar.

Thais C. Morata, Ph.D. National Institute for Occupational Safety and Health Cincinnati, OH USA 5 de agosto de 2010 